\title{
The origin of Shang civilization: A brief survey from Neolithic age through the transitioning cultures beside Huang Ho and Yangtze River
}

\author{
Aditya Shankar Chattopadhyay \\ Department of History, Presidency University, Kolkata \\ DOI: 10.29322/IJSRP.10.07.2020.p10379 \\ http://dx.doi.org/10.29322/IJSRP.10.07.2020.p10379
}

\begin{abstract}
Just like Mesopotamia, Egypt or Indus valley of India, Ancient China was also presented a wonderful Bronze Age civilization. It was $1^{\text {st }}$ thought by mainly Eurocentric and diffusions scholar that Chinese civilization was not an indigenous civilization and it was totally influenced by central Asia and India and so on. But recent researches and the excavation work by Academia Sinica since 1920 revealed so many data about its purity and indigenous roots along with few influence from outside. However Neolithic age arrived in China at about 9000 BC and it had 2 origins- a) Millet farming based Neolithic culture beside Huang Ho river b) Rice farming based Neolithic culture beside Yangtze River. The $1^{\text {st }}$ Neolithic Yongshao culture had grown up very near to the Zhoukoudien cave where we found the fossils of Peking Man. However the Shang civilization existed from 1800 to 1100 BC. In this paper I mainly give a very brief discussion about the transitioning Neolithic, Chalcolithic and Bronze Age cultures through the passage of time in which I try to find out origin of metallurgy, class stratified society, urban settlement and few traits that is related with a Bronze Age "Civilization". As an undergraduate student of History, I mainly used few secondary sources like books on this topic written by Indian, Chinese and other great scholars.
\end{abstract}

Index Terms- Yangtze River, Huang Ho River, Yongshao culture, Hemudu culture, Longshan Culture, Liangchu Culture, Eriltou Culture, Xia Dynasty, Shang Dynasty

\section{INTRODUCTION}

$\mathrm{J}_{\mathrm{c}}^{\mathrm{u}}$ ust like the south west Asia, Europe, Central Asia, Far east China is also an important place of Neolithic culture. The Bronze Age in china is begun around $1600 \mathrm{BC}$ and with the help of the writing evidence "ORACLE BONE INSCRIPTION" Shang civilization is considered the earliest or the $1^{\text {st }}$ civilization of china. This civilization was existed between $1700 \mathrm{BC}$ to $1000 \mathrm{BC}$ that mainly corresponded the middle of the china's Bronze Age .Ancient china has 3 big dynasties they are-Xia ,Shang, Zhou. In this time the $1^{\text {st }}$ archaic monarchy of china established. There is a controversy that not Shang dynasty but the Xia dynasty was the $1^{\text {st }}$ dynasty of china. Legends talk about the Xia dynasty prior to the Shang but there is no contemporary written records to prove this point even though text written later than the Shang dynasty also mention the existence of Xia dynastyi. Apart from the controversy,
I will try to discuss very briefly how the civilization formed from a Neolithic settlement and culture through the transitioning cultures.

\section{GeOgRAPHICAL EXTENT OF THE SHANG CIVILIZATION:-}

Just like the other ancient civilization, ancient Chinese civilization or the Shang civilization was build up beside river of Huang how or "Yellow River" and some part beside Yangtze river. This civilization was situated in the middle south and western part of china. This place mainly holds the now days Hubei, Shandong, Shanxi, Anhui and some part of the Jiangxi province. The Neolithic culture of china mainly flourished especially in this area from which the Shang civilization rises.

\section{HOW WE DEFINE THE ORIGIN OF THE CIVILIZATION FROM THE NEOLITHIC SETTLEMENT:-}

The ancient Chinese civilization was grown beside the river Huang how and few parts of Yangtze, that I mentioned before. In between $6000-2000 \mathrm{BC}$, this river changed its direction for so many times. After the extreme cold and dry conditions of the last glacial period, the climate warmed up considerably during 7500$3000 \mathrm{BC}^{\mathrm{ii}}$. The main Neolithic culture was flourished in this time mainly however another phase of climatic change happen then to cold and dry environment that continues till the modern times . Scholars like D.N. Keighley is also opined the importance of climate and environment behind the background of Neolithic and chalcolithic settlements of China. The fertile river valley of Huang ho and the climate, environment of that time made the stage for the ancient Chinese civilization.

So when we define a civilization, we have to analyse the origin of such civilizational traits through transforming cultures. Here when we looked at the various Neolithic and chalcolithic culture of China, we got a brief idea about origin of a sedentary society to a complex-class stratified society that moved towards a civilization. We have to analyse the culture with the relationship between various traits of a civilization.

\section{EARly NeOlithic CUltures of ChinA:-}

The Neolithic age arrived in China at around 6500 BC. China has 2 origin of Neolithic culture and they are millet based 
Yongshao culture in Huang ho valley and rice based Neolithic culture in Yangtze valley. The $1^{\text {st }}$ one was known as Yongshao culture (5000-3000 BC) excavated ${ }^{\text {iii }}$ by J.G. Anderson in 1927 and the rice based culture was known as Hemudu culture ${ }^{\text {iv }}$. Those cultures are contemporary but hardly showed any kind of similarity due to its different background of climate and environment. However that culture is not so much important for the origin of Shang but we cannot deny its relevance for the origin of pottery, classic tripod vessels and jade object through Longshan and Liangzhu culture which were an integral part of Shang art and architecture. From that phase we found the origin of civilizational traits in China.

\section{LONGSHAN CULTURE IN HUANG HO VALLEY (APP. 2700-} 2000 BC)v :-

This culture includes manufacturing of wheel turned pottery, copper, bronze, jade ornaments, possible origin of writing and lastly most important-evidence of town society. Located at the hubs of regional settlement networks' are large population centres characterized by new archaeological features. The rammed earth walls which indicates a social system that was that was significantly more complex that 'Yongshao village'vi. So many towensite excavated in Henan, Sichuan and Shanxi province. The largest town settlement is excavated from Taosi in Shanxi provinces the best site to show up gradation towards an urban civilization in this culture.

Here we find wheel made and well fired pottery and copper made pottery. With the early evidence of metal this is opined by the scholars that the metal vessels were limited for the elites.

Many scholars tried to find writing evidence in Yangshao, Cishan pottery decoration but they did not succeed so much. But recent archaeology has turned out a new type of material. K. C. Chang noted that at a large number of prehistoric sites incised marks, apparently of a symbolic character, have been found on pottery vessels or potsherds. These sites show date from early Neolithic Yongshao to just before the historic period and they were found through entire yellow river valley of China. ${ }^{\text {vii }}$ According to Prof. Chang the mark in the pottery is an evidence of the pottery maker's name, pottery shops or the story of the clans who were made pottery. Even so many Longshan site shows such evidence of writing in pottery shards and it is very similar in contemporary Liangchu culture in Yangtze valley. On the each of the two shreds the graphs from from an internally related sequence of ideas that can only be connected through language ${ }^{\text {viii }}$.Therefore many scholars suggest the decoration and symbols of pottery as an early specimen of Chinese writing- an essential trait of a civilization that we found in chalcolithic Longshan culture.

The writing yet did not decipher but undoubtedly it was used for spiritual and administrative function. The evidences bring dramatic social changes in Longshan culture and many scholars suggested the probability of "Archaic state". That is why not only archaeologists found so many evidence of palace, walled city and residence of common people but also found so much evidence of warfare. In Taosi sites, 280 hec. Rammed earth belonged to the elite residents were separated from those of commoners by dividing walls. ${ }^{\mathrm{ix}}$ Violence in the society is also reflected in the finding of skeletons in a dry well in Longshan sites which show the struggle of the then rulers to maintain their position.
Social stratification and class differentiation is also reflected in Longshan burial culture. Excavation in Taosi showed so many burial which were divided in 3 sub divisions-large scale with so many grave goods mainly jade items, medium scale grave with few goods and lastly small sized graves with no grave good. This social stratification is also apparent in contemporary Liangchu culture which I will discuss now.

In Longshan culture we undoubtedly said that this culture gave the birth of early language and highly stratified society that is so important for an ancient urban civilization.

\section{CONTROVERSY REGARDING THE RISE OF CIVILIZATION IN YANGTZE AND HUANG HO VALLEY AND INFLUENCES OF YANGTZE VALLEY IN THE XIA AND SHANG CIVILIZATION:-}

Previously I discuss about the rise of complex society and pre-states in Yangtze valley, now I discuss about the rise of a civilization or urban culture in southern china. Recent research breaks the myth regarding the Chinese prehistory that Huang ho valley is the backbone of Chinese civilization. Prof. Xu Chaolong wrote an interesting paper on this topic. Seeing the industrial evaluation and development in south china from 1960, he tried to find out the urban culture of this site in early age. Many scholars research indicate that this place gives birth of a civilization much older than Shang but it is still going on and archaeologists thought that this urban culture had a great influence in urban culture, stratified society of Xia dynasty. Well Liangchu culture is one of the important cultures of this site and special for jade ornaments. In a site 547 artefacts found with a single skeleton. The grave goods are an assemblage of pottery vessels, shark tooth, ivory and jade object. The grave clearly suggests the grave of a political and leader or lineage chief ${ }^{\mathrm{x}}$. Such burial reflects the highly stratified society with a clear distinction between rulers and the ruled

Here I will discuss about the urban cultures of later liangchu culture and the excavation in the upper valley of Yangtze River. There the archaeologist found evidence of rapid increase in population. This period belonged to the Quchiling culture (3200$2600 \mathrm{BC})$. Each of the settlements was surrounded by a large rammed wall and a wide moat. Inside there was a large production sites located in a different places and an area thought to include palace or temple located in higher tableland in the centre of the site. ${ }^{\mathrm{xi}}$ Here we found high walls that were used almost every urban site. There we found the diverse culture in burial. In the cemetery outside the 'city wall' a jade objects were found in tombs of the rich while nothing was found in the burial of the common people or poor ${ }^{x i i}$.Finding of so many artefact only in the elite graves suggested a highly stratified society. We found a large 'city' on the top, several smaller cities having the same configurations. The walled city might have been the result of specialization of production and also some evidence of war that happened frequently on that period. Chaolong said "we can see a developed society with apparent factors of urbanism and civilization"xiii.

The period of 3000-2000 BC is the most prosperous age of Yangtze river valley and maintained its development for so many years. But archaeology shows a dark period between 2000 to 1050 $\mathrm{BC}$ where all development we see in Huang ho valley. Though very few sites provides some artefacts that are contemporary of Shang period. 
So with so many excavations, Yangtze valley shows a new civilization that is quite older than "Yellow river civilization". Though there is no written evidence but still the discovery of such evidence really challenged the "Yellow river civilization" the backbone of ancient china. But my topic did not base on this controversy. Chaolong said around 2200 2000 BC when Yangtze civilization enjoyed the peak of its development, suddenly collapsed and disappeared from the delta region. Thick layer of mud in every Liangchu site proved that earliest civilization of china may have been destroyed by flood. We see the rebirth of this culture in Zhou period.

So if the Shang civilization is the $1^{\text {st }}$ civilization of china so what happened with the Yangtze valley? The main cultural features of Liangchu culture was moved to the middle valley of Huang ho and amalgamated with the mainstream of Chinese civilization. This gives birth of a new culture called 'Eriltou' which was raised on the middle valley of Huang ho and flourished the Xia dynasty. Now I will discuss Eriltou culture and Xia dynasty that is the last step towards Shang civilization.

\section{ERILTOU CULTURE AND XIA DYNASTY:-}

Neolithic Longshan culture showed rising of chiefdoms, states, and this culture is followed by Eriltou culture (1900-1600 $\mathrm{BC})$. This culture named after the findings in the city of Eriltou in the Henan province in 1957 south of Huang ho river. We previously discuss about the Liangchu culture in Yangtze valley that was destroyed at around $2000 \mathrm{BC}$ by devastating flood. So the culture migrated to this part of china and merged with Longshan culture. Similarly like Longshan culture, this culture this culture showed so many up gradations of social structure, town plan, pottery culture and metallurgy. In the later phases a complete pal ace structure excavated surrounded by high walls in all 4 sides. Large palace complex was contrasted by small huts and houses indicating class differentiation. The remains of graves excavated also reflect such a social chasm. Another important feature of this culture is the bronze metallurgy that reached the highest stage of development ${ }^{\mathrm{xiv}}$. Eriltou artisans produced verity of bronze tools with so many bronze weapons like battle axe, dagger, axe etc. All the artefacts were found in either elite groups or near palace area indicating royal control over bronze. All this this features raise the question of state formation or early civilization.

Most scholars agree now that after the beginning of 2 nd millennium BC, something that can be properly called a state had indeed arisen in China, particularly in western Henan ${ }^{\mathrm{xv}}$.Many sites of the relevant culture between 1900-1600 BC supports this fact. So many excavation and research over this culture proved Xia dynasty, the so call $1^{\text {st }}$ dynasty of china is the contemporary part of Eriltou culture. This dynasty has a great influence from the Yangtze valley settlements. The founder of the dynasty $\mathrm{Yu}$ the great was also a man who came from that part. He was the $1^{\text {st }}$ ruler who was successfully able to establish flood control measures to protect the valley from inundations. Recent excavation traced his capital in Dengfeng, Henan province which was a large settlement. King Yu and his successor ruled the Xia dynasty for a long time. The dynasty mainly covers the middle and few part of southern china in Huang ho, Yangtze valley. Well it is a matter of controversy that is Xia the $1^{\text {st }}$ civilization of china? Well, we do say so only for the absence of written evidence. Ancient china has
3 dynasties- Xia, Shang, Zhou. Father of Chinese history Sima Qian selected Xia from among many contemporary polities probably because during the earliest part of the Chinese Bronze Age or three dynastic periods Xia was most powerful ${ }^{\mathrm{xvi}}$. So we can say that Xia dynasty and contemporary Eriltou culture succeeded to unify the ancient Chinese province and made the platform for Shang dynasty that arrived at around $1700 \mathrm{BC}$.

\section{RISE OF SHANG DYNASTY:-}

The period of Shang dynasty (1700-1000 BC) corresponds to the middle of the china's Bronze Age. Xia dynasty did not have any written evidence that we found in Shang dynasty in oracle bone inscription. The city of Eriltou had fallen in the late $16^{\text {th }}$ century B.C. Recent systematic C-14 dating has fixed the end the last period of the cultural deposit in Eriltou. $1554 \mathrm{BC}$ is suggested as the as the $1^{\text {st }}$ year of the Shang civilization by so many historian. With the establishment of this civilization we enter into the historical period when North china was ruled by royal dynasty whose outline history is testified by the excavated written records in a close match with the received tradition on Shang royal genealogy. ${ }^{\text {vii }}$

From the Oracle bone inscription we found so many facts regarding the Shang dynasty. This written evidence belongs to the later Shang period that is why we got the names of the kings, capitals, rituals and so many features that is essential for a civilization. According to the legend Cheng Tang founded this dynasty after defeating the ruler of legendry Xia dynasty and their $1^{\text {st }}$ capital was Xibo. Written record showed that not only Xibo but also Shang has 7 capitals in their almost 600 years rule. Archaeological findings indicate that the focal point of the Shang dynasty was a triangular area in the Henan Province covering 5 major cities of Anyang, Luoyang and Zhengzhou. The findings also suggested the high social stratification that we see in the previous culture especially in Anyang. Kings, priests and royal family member was in the upper class- the exclusive users of bronze for rituals and war. Farmer, craftsman comprised the lower strata of Shang society. ${ }^{\text {xiii }}$

Well in that way the $1^{\text {st }}$ ancient civilization of china formed after passing so many Neolithic and chalcolithic culture.

\section{Conclusion:-}

There are many problems to reconstruct the of Chinese history. The history is written mainly based on few archaeological findings and mainly on the myths, legends etc. Well still many scholars suggest Xia as the $1^{\text {st }}$ civilization of china but the research still going on. . As K.C. Chang said that Chinese Neolithic culture went through a series of changes as it's gradually progressed to higher and higher cultural levels and finally the process of evaluation gave the birth of a pristine civilization in china. ${ }^{\text {xix }}$ The changes we see in the Neolithic Yongshao, Longshao, Liangchu, Daxi cultures and finally Eriltou culture. The evaluation in culture showed social stratification, diverse pottery culture and obviously a state formation the gave a birth of civilization. And at last I will say that Chinese civilization is influenced by other was just a myth of old researches and according to Prof. Chang Chinese culture is indigenous and it's 
evaluation from barbarism to civilization follows same recurrent pattern that the we see around the other part of the world ${ }^{\mathrm{xx}}$.

\section{AUTHORS}

First Author - Aditya Shankar Chattopadhyay, B.A, Semester2 Department of History, Kolkata, Presidency University, E-mail id:- adityashankarchattopadhyay@gmail.com,Contact no.:9330261847s, alternate email address (if any), contact number.

\footnotetext{
' Rakesh Kumar, Ancient and medieval word: From Evaluation of Humans to the Crisis of Feudalism, Sage Texts, New Delhi (2018), Page- 132

ii Ibid, Page-127

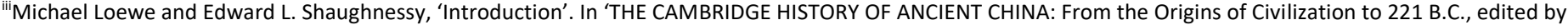
Michael Loewe and Edward L. Shaughnessy, Cambridge University Press, New York (2006), Page- 4

iv Brian Fagan and Chris Scarre, Ancient Civilizations, Rutledge, New York (2013), Page- 158

${ }^{v}$ Ibid, Page- 159

vi Li Feng, Early China: A Social and Cultural History, Cambridge University Press, Cambridge (2013), Page- 30

vii K.C. Chang, Art, Myth and Ritual: The Path to Political Authority in Ancient China, Harvard University Press, Massachusetts (1983), Page- 81 to 84

viii Li Feng, Early China: A Social and Cultural History, Cambridge University Press, Cambridge (2013), Page- 37

ix Brian Fagan and Chris Scarre, Ancient Civilizations, Rutledge, New York (2013), Page- 160

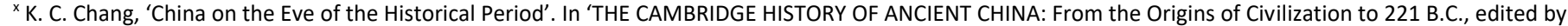
Michael Loewe and Edward L. Shaughnessy, Cambridge University Press, New York (2006), Page- 61

${ }^{x i}$ Xu Chaolong, 'VIEWING THE RECONSTRUCTION OF THE FRAMEWORK OF CHINISE CIVILIZATION', Japan Review, No.9, 1997, Page- 211

https://www.jstor.org/stable/25791009

xii Ibid, Page- 211

xiii Ibid, Page- 212

xiv Rakesh Kumar, Ancient and medieval world: From Evaluation of Humans to the Crisis of Feudalism, Sage Texts, New Delhi (2018), Page- 131

xv Li Feng, Early China: A Social and Cultural History, Cambridge University Press, Cambridge (2013), Page- 42

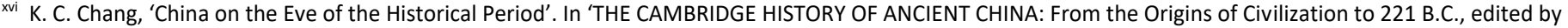
Michael Loewe and Edward L. Shaughnessy, Cambridge University Press, New York (2006), Page- 73

xvii Li Feng, Early China: A Social and Cultural History, Cambridge University Press, Cambridge (2013), Page- 54

xviii K. C. Chang, 'The Continuing Quest for China's Origins ii. The Shang Civilization', Archaeological Institute of America, Vol. 30 , No. 3, May 1977, Page- 189

https://www.jstor.org/stable/41706153

xix Ibid, Page- 195

${ }^{x x}$ Ibid, Page-195
}

\section{Author}

Aditya Shankar Chattopadhyay

B.A, Semester- 2

Department of History, Kolkata

Presidency University

E-mail id:- adityashankarchattopadhyay@gmail.com

Contact no.:- 9330261847 